UDK: 81'373.23(497.6)

DOI: $10.33669 / \mathrm{KJ} 2021-32-05$

primljeno / received: 29.7.2021.

prihvaćeno / accepted: 11. 12.2021.
Izvorni naučni rad

\section{Indira Šabić}

Filozofski fakultet Univerziteta u Tuzli

Vukovarska br. 2, Tuzla

Bosna i Hercegovina

indira.sabic@unitz.ba

\title{
Zmaj od Bosne ili ga vile nose - mitski i magijski motivi u prezimenima Bosne i Hercegovine
}

Sažetak: Mitologija i fantastika, kao interferirajući elementi daleke prošlosti, prožimaju se sa savremenim jezikom, a dodirna tačka im nije samo usmena književnost nego i onomastika. Ti elementi, iako prividno pohranjeni u prošlosti, revitaliziraju se u novim oblicima kao prezimena. U radu se analizira semantika tih prezimena, uz etimološka i tvorbena rješenja. Kako se od mitskih motiva više ne tvore prezimena, jer je ta kategorija odavno zatvorena, ovakva specifična prezimena su vrijedna naučnoga proučavanja i korpusnoga pozicioniranja. Zato, izvorno navedeni, opisani i analizirani, primjeri u ovome radu imaju značajno filološko, etnološko i antropološko blago.

Ključne riječi: antroponimija, onomastika, prezimena, mitologija, divovi, vile, zmajevi, slavenski paganski bogovi

\section{Uvod}

Narodna su predanja valjani izvori za proučavanje starine jer su predstavljala neotuđivi dio svakodnevnice, kada je društveni život, zarad očuvanja vrijednosti koje mogu udovoljiti zahtjevima porodične sreće, tvorio priče u dokonim razgovorima u kojima je skup uživao slušati o lukavstvu, lucidnosti, duhovitosti ili hrabrosti. Predaje, mitovi, legende, mitološke pjesme i sl., vitalno su se odupirale vremenu, kolale od grada do sela, od jedne do druge socijalne i nacionalne sredine, naglašavajući stara vjerovanja u svježijim oblicima. Ta stara vjerovanja su 
se uglavnom svodila na paganska, vjerovanja u nadnaravna stvorenja i natprirodne pojave, da svijetom upravljaju sunce, mjesec, zvijezde, gromovi, munje, vile, zmajevi, duše predaka. (usp. Nedić 1977: 21) Takva promišljanja, ukorijenjena stoljećima, nastavila su da žive i po dolasku monoteističkih religija, u tolikoj mjeri da im je tragove moguće naći ne samo u živim ustima koja i danas kazuju predanja nego pozamašno u antroponimiji i toponimiji. Tako su brojna prezimena motivirana čudesnim ili čudovišnim stvorenjima, antropomorfnim ili zoomorfnim bićima te likovima paganskih božanstava. U toj skupini motiva prednjačili su: 1. vile i razne nemani: divovi, vukodlaci, zmije, zmajevi; 2. slavenski paganski panteon - teonimi; 3. nebeska tijela - kosmonimi; 4. elementi kulta vatre. $U$ interakciji s natprirodnim silama, identificirajući se kao žrtve iskupljenja i moćni krvnici, ljudi su oblikovali zasebnu skupinu prezimena koja su motivirana magijskim elementima, a koja svjedoče svestranu povezanost čovjeka s prirodom, od razvijenoga kulta narodne medicine, ovladavanja prirodom, do slavenskoga panteona koji je inicirao važnost slavljenja prirode. Magiju su provodili posebno izučeni, a prirodom i višim silama nadareni pojedinci, koji su različito nazivani: vračari, gatare, faletari, karapandže, bajalice, vještice ili proroci, preko čega su često identificirani. U nastavku rada se analiziraju prezimena ovoga tipa na način da im se prilazi iz ugla onomastike, mitologije i etnolingvistike.

\section{Korpus istraživanja}

U naprednim civilizacijama, statistički su podaci sumirani i bilježeni još od davne historije, kada su pravljeni spiskovi inventara, materijalnoga dobra, džakova žitarica, robova i općenito stanovnika, kako bi se moglo oporezivati i slati u rat. Naučnom analizom takvih statističkih podataka naučnici mnogih usmjerenja oblikovali su potpuniju sliku prošle stvarnosti. Međutim, trebalo je proći puno vremena dok popisi stanovništva nisu postali obuhvatniji, sa obilježjem pune antroponimijske formule (ime + prezime), i tako referentan izvor podataka za onomastičku analizu i druga problemska pitanja. Prvi takvi popisi stanovništva na terenu Bosne i Hercegovine su zapisi u raznim defterima 
ili sidžilima, iz vremena osmanlijske uprave, dok nešto sistematičnije matične knjige bilježe katolici po župama tek od početka XVIII stoljeća. To znači da su se obuhvatnije informacije o identitetima i posjedovanju počele definitivno prakticirati tek tokom austrougarske uprave. Raniji su popisi važan izvor podataka u historiografiji, ali za statističku obradu i demografske analize tek ih je primjena načela kritičnoga trenutka učinila naučno relevantnim izvorom podataka. U kontekstu savremenoga aparata, posljednji popis stanovništva u Republici Bosni i Hercegovini proveden je 2013. godine. Zbog visokoga stepena vjerodostojnosti, savremeni popisi stanovništva predstavljaju reprezentativan i relevantan izvor za suštinska etnološka, sociološka, lingvistička ili druga istraživanja. S tim u vezi, primarni izvor koji je temeljem istraživačkoga korpusa ovoga rada jeste izvještaj Popisa stanovništva Republike Bosne $i$ Hercegovine iz 2013. godine, zaprimljen od Agencije za statistiku Bosne $i$ Hercegovine, zatim razni popisi iz osmanlijskoga i austrougarskoga perioda, a kako bi ovaj rad ponudio temeljitije informacije o bosanskohercegovačkim prezimena kojima su u procesu motiviranja poslužili mitski i magijski elementi, infiltrirana je i građa iz različitih drugih publikacija koje su istaknute u popisu izvora ovoga rada.

\section{Vile i nemani}

Vile se, kao glavna ženska božanstva čitavoga južnoslavenskog melopoetskog folklora, nalaze u samome vrhu pojava i u temama i u motivima bošnjačkih mitoloških pjesama... U njima se mahom opjevaju vile kao čudesna ili čudovišna stvorena, koja grade bijele gradove i druga stamena zdanja, ali i kao bića koja se uvijek umiju spretno izbaviti iz nepovoljnih prilika. U određenim okolnostima vile mudrim savjetima pomažu ljudima kada se ovi nađu u nevolji ili kada su u nedoumici šta činiti. (Efendić 2014: 108)

Poslovična mudrost vila ulazila je različitim putevima u narodna vjerovanja, pa su zabilježeni stihovi kojima vile savjetuju ljude: Ne per' nogu od nogu, / Ne pij vode prilegom, / Ne bij konja povodcom, / Ne bij vola toljagom, I ne čin' sam seb’ sihira! (Efendić 2014: 110 prema Bradarić knj. V br. 139)

Kolika je bila zaokupljenost vilama u mislima domaćega čovjeka svjedoči i motiv ženidbe čovjeka vilom u brojnim pjesmama bošnjačke i 
susjednih tradicija. Do ženidbe je dolazilo kada je vila ostajala bez krila i košulje (koji se odlažu kada se vile kupaju u jezerima ili gorskim potocima), nakon što ih je sam čovjek otuđio, ne bi li vilu zadobio. (usp. Efendić 2014: 111) Opsesivnost vilama izrodila je i vilinski motiv u antroponimiji, pa je npr. u Engleskoj moguće utvrditi lično ime Alfred u značenju vilenjaka savjetnika < engl. aelf - vilenjak + engl. raed - savjet (Šimundić 9 :2006), a u domaćoj antroponimiji prezimena:

Vila, Vilenica, Vilandečić, Vilogorac, Vilić (stsl. vila - mitološko mlado i lijepo žensko biće obdareno magijskim moćima)

Prezimena su mogla biti izvedena i iz nekog toponima koji je motiviran ovim čudesnim gorskim pojavama: Vilina šuma kod Čajniča, Vilinac kod Čvrsnice, Vilenica kod Travnika, Vilina Bukva kod Kalinovika, Vilina kosa kod Bogodola, Vilino Polje kod Bjelašnice, Vilišta na Jahorini itd. (Popović 1935: 240)

Ognjevita, krilata neman, zmaj ili aždaha/aždaja je mitološko biće, silovito, goropadno i osvetničko. U mitološkim pjesmama uglavnom otima lijepe djevojke koje ne pristaju na suživot sa njim, zbog čega se zmaj rasrdi te ljepoticu najprije usmrti, a zatim je baci lešinarima na zemlju: Stara majko, Bogu mila bila, / Ti ne tuži i ne žali šćerke / Bolje joj je u zemljici biti / Nego zmaja krilatog ljubiti! (Kosta Hadži Ristić, Krilma mahnu zmaju ognjeviti, 2-3, prema Efendić 2014: 114) Figure aždaje i zmije učestale su i na bosanskoj srednjovjekovnoj stećkovnoj ornamentici: kod Čapljine, na području Donjeg Hrasna, nalazi se stećak s raznim figurama i likom dviju aždaja (zmajeva), međusobno isprepletanih; slično je u selu Hodovu kod Stoca; u Gornjem Hrasnu kod Čapljine uklesana je figura aždaje itd. (Vego 1980: 356). Nemani su kao motivi pronađeni u sljedećim prezimenima:

Aždajić (pers. ežderhā, eždehā, ežder - zmaj > bos. aždaha, aždaja mitsko biće zmijolikoga oblika sa nogama, krilima i sa jednom ili više glava; Škaljić 1989: 108)

Zmajevac, Zmajević (stsl. zmii - zmaj, krilata neman)

Alavuk (< tur. ala - zmija, zmaj + stsl. volkb - zvijer iz porodice pasa)

Prezime Alavuk potvrđuje da je krilata neman zmaj imala mogućnost svestranije preobrazbe, pa i u vuka, što je isto ili blisko slavenskome 
konceptu vukòdlaka, što je "etnol. čovjek koji za puna mjeseca poprima izgled i ćud vuka; likantrop” (Anić 1996: 1183). U zapadnome dijelu južnoslavenskoga jezičkog i kulturnog područja, vuk je totem i javlja se kao inkarnacija predaka te prvobitni, životinjski oblik staroga, pretkršćanskoga vrhovnog božanstva smrti i donjega svijeta (usp. Čajkanović 1941: 17-19, 32-33, 68). Asocijacije vukova sa smrću i svijetom mrtvih su u historiji bile široko rasprostranjene u europskom i indoeuropskom geografskom i kulturnom prostoru, a negativnome percipiranju i projiciranju ove životinje doprinijelo je prilično rašireno zapadnojužnoslavensko pučko vjerovanje da vukovi osim stoke jedu i ljude. To je jasno sagledljivo i u narodnim izrekama: što vuk ulovi i u čeljusti uhvati, to se ne vraća u značenju što smrt uzme, ne vraća se, jednako kao i u kletvi: vuci te pojeli.

U slavenskome svijetu vukodlaci (rus. волки-оборотни, rum. volki-oborotni, bos., hrv., srp. vukodlaci) označavaju hodajuće mrtvace koji poslije smrti uznemiruju svoju rodbinu i ukućane te pri tome mogu primiti oblik raznih životinja, najčešće vuka, psa ili drugih zvijeri (Svešnikova: 130-131). “Toj kategoriji demonskih mrtvaca na zapadnojužnoslavenskom području odgovara kategorija vampira.” (Plas 2010: 82) Za Anu Radin (1996: 23), autoricu opširnih studija o vjerovanju u vampire u Srba, vuk je najčešća metamorfoza "vampira koja je doprinela izjednačavanju demonskih pojava vampira i vukodlaka”. Etnolozi se slažu da su se značenja vampira i vukodlaka na štokavskome prostoru stopila te su stoga termini postali potpuni sinonimi (Đorđević 1953: 150; Schneeweis 1935: 277; Čajkanović 1941: 172). Termin vukodlak, koji je izvorno označavao čovjeka vuka, tj. čovjeka sposobnog da privremeno preuzme oblik vuka, desemantiziran je, ali je lik vampira preuzeo osnovnu osobinu izvornoga vukodlaka, naime sposobnost mijenjanja pojavnoga oblika (Slavjanskie drevnosti I, pod vampir, volkolak; Burkhart 1989: 69, 94, 99). Razlog za sinkretizam vampira-vukodlaka po svoj prilici treba tražiti u njihovoj moći preobrazbe (Plas 2010: 83). Ova neman motivirala je prezimena:

Drakul, Drakulić (lat. drăco > bos. drakula - natprirodno čudovište, vampir, vukodlak; kategoriji demonskih mrtvaca na južnoslavenskom području i u Europi odgovara kategorija drakula; Žepić 1985: 87) 
Divovi su u slavenskome svijetu najstariji oblici poganskih bogova. Slaveni su ih opisivali pridjevima divan i divlji i otuda dolazi do semantičkoga proširivanja, npr. u sintagmama tipa: divlje voćke i divlje životinje, koje su bogovima bivale posvećene. Da je u domaćoj narodnoj predaji bila prisutna tema o divovima svjedoče brojne legende, npr. o postanku srednjovjekovnih nadgrobnih spomenika, stećaka, za koje je narod vjerovao da su po zemlji razbacani usljed divovske igre kamena s ramena. Također, do Prvog svjetskog rata u šumama Bišine (općina Živinice), postojali su ostaci nekadašnjega pepelarenja - razbijeni željezni kotlovi u kojima se spaljivalo hrastovo drvo, zarad proizvodnje sapuna, a za koje je lokalno stanovništvo vjerovalo da su ostaci divova i duhova koji su gospodarili šumama. (usp. Franković 1987: 252) Ovo čudesno biće motiviralo je sljedeća bh. prezimena:

Divac, Divčić, Divić, Divović, Divoš, Divović, Divanović, Divjak, Divjakinja, Divković, Divljan, Divljanović (stsl. divø - čudo, čuđenje > bos. div - mitološko biće ljudskog izgleda, natprirodne veličine i snage gorostas, džin, demon; stsl. divbnz > bos. divan - čudesan, fantastičan; stsl. divii > bos. divlji - nije pitom, neukroćen, van kontrole)

Kako je vidljivo i u interpretaciji, u bosanskome jeziku su se u odnosu na leksemu div razvili sinonimi gorostas i džin. Oblik džin se razvio u orijentalnome jezičkom okruženju, pa oblike s osnovom div-nalazimo u turskom dev i perzijskom jeziku dìv u značenju "demon”. Kako je orijentalni utjecaj na bosanski jezik bio snažan, po očekivanju je i džin poslužio kao motiv u prezimenima:

Džin, Džinalija, Džinić, Džino, Džinović, Đinović, Đino (ar. ğinn > tur. cin > bos. džin - natprirodno, duhovno, nevidljivo, mistično biće, demon, duh)

Istoznačno prethodnim oblicima, apstraktna imenica bijes je zabilježila semantičko širenje pa se i njome imenovala ova gorostasna neman: Bijesović (<stsl. bêsb - zao duh, demon).

\section{Paganski panteon}

Istočni i južni Slaveni priznavali su i slavili boga Peruna, božanstvo koje označava gromovnika. U dosad rekonstruiranoj južnoslavenskoj 
pretkršćanskoj mitologiji, nebeski bog Perun uživa mjesto vrhovnoga boga, stolujući uvijek na gori, planini ili vodi. "Perunov kult na uzvisinama nad vodom potvrđuju i južnoslavenski toponimi” (Katičić 2007: 75), pa se po očekivanju, zbog slavenskoga porijekla s jedne strane i brdsko-planinske domene s druge, ime Perun zadržalo u bh. toponimima, antroponimiji, pa i fitonimiji npr u "imenu biljke perunika ili bogiša, koja se u Hercegovini poštovala na način da su je seljaci ritualno donosili u crkvu na Uskrs, da se blagoslovi. Perunikom su se kitili, a dio ubranih cvjetova su ostavljali na oltaru u crkvi, što je svakako paganski običaj" (Vego 1980: 415). U pogledu toponima motiviranih ovim imenom, Milenko S. Filipović (1948: 64) je zaključio da se redovno odnosi "na izvore i visove, dakle na takva mesta koja su oduvek služila kao kultna i koja po svojoj suštini dobro odgovaraju kao božanstvo koje vlada gromom, munjom i oblacima”. Na taj je način imenovano brdo Perun kod Kraljeve Sutjeske. Spomen na ovo božanstvo očuvan je i u prezimenima:

Perun, Peruničić, Perunović, Peruš, Perušić, Perušina, Perušinović (< prasl. ${ }^{\star}$ perunz - 1. grom, munja, 2. slavensko božanstvo, gromovnik ili bog munje i groma i taj njegov nebeski aspekt određuje vrhovni autoritet kao i kod drugih pretkršćanskih gromovnika Zeus, Thor)

S kultom Peruna kasnije je usko povezan sv. Ilija, koji je također prihvatan kao gromovnik, gospodar munja i oblaka, zato očuvani toponimi motivirani ovim imenom označavaju uzvišenja i brda: Ilijino brdo kod Trebinja i kod Posušja, brdo Ilinčica kod Tuzle, planina Ilija kod Ljubinja, brdo Ilija kod Mesara itd. Slaveni su vjerovali da se Ilija vozi u posebnoj kočiji po oblacima tako da ga se svaka duša na zemlji boji. $\mathrm{O}$ tome su nastajale brojne pučke priče i pjesme, u čast sv. Ilije i pred strahom od njeg (Vego 1980: 415). Danas je u Bosni i Hercegovini moguće naći sljedeća prezimena motivirana ličnim imenom Ilija: Ilijašević, Ilić, Ilijić, Ilinčić, Ilišević.

Marko Vego (1980: 411) iznosi tvrdnju da je naziv Maglo keltska riječ koja se pojavljuje uz božanstvo Slavena u značenju Veliki, a zatim i hipotezu da su s tim u vezi i imena brda Magovik kod Lištice blizu Mostara, grada Maglaja, vjerovatno planine Maglić kod Sutjeske u istočnoj Hercegovini, a onda i homografno prezime Maglić. 
Slaveni su poštivali šume, stabla razne vrste, od lipe do hrasta, i uz njih se molili svojim božanstvima i prinosili im razne žrtve, od poljoprivrednih plodova do životinjskoga mesa. Takve rituale uglavnom su obavljali u gorju, na planini, visočju ili poriječju kao kultnim mjestima gdje su po vjerovanju nazočila božanstva, prema kojima su i lokaliteti imenovani. Tako se grad Stolac u ranije doba srednjeg vijeka spominje pod imenom Vidošić, Vidoški grad u Vidovu polju, obližnji lokalitet blizu nekropole Radimlje je Vidoštak, zatim planina Viduša kod Trebinja itd. Bilo da su nastala iz ličnih imena, patronima ili avonima, ili iz toponima, izgledno je da se prezimena: Vidak, Vidaković, Vidić, Vidićević, Vidačak, Vidaček, Vidačić, Vidačković, Vidanović, Vidanovski, Vidarić, Vidojević, Vidoš, Vidović, Vidušin, mogu dovesti u vezu sa slavenskim božanstvom Svetovidom, odnosno Vidom, kojeg je u kršćansko doba zamijenio sv. Vid (< lat. Vitus - koji je životan; usp. Šimundić 2006: 360). "Umjesto Svetovida, Sloveni kao kršćani uzimaju svoga svetitelja za zaštitnika, i to u prvom redu sv. Vida ili sv. Vita" (Vego 1980: 416). Identično Vegi i Jovan Deretić (2007) je, u prohodu kroz srpsku usmenu liriku, zaključio da su likovi iz mitoloških pjesama nakon primanja kršćanstva zamijenjeni novim vjerskim motivima te da je to sve više uzimalo maha, dok je ono prvobitno, animističko, ostalo da živi i dalje.

\section{Nebeska tijela}

Osim vila, zmajeva i divova, u domaćem svjetonazoru, narodnoj predaji i vjerovanju, antropomorfna svojstva su primala i nebeska tijela: Sunce, Mjesec i zvijezde. Još od najstarijih vremena ljudskoga postojanja, veliki značaj su imale figure sunca i mjeseca, punoga ili polumjeseca s raznim okretanjem krakova prema stranama svijeta. To je graničilo s čovjekovom opsesivnošću, vidljivom u mitu o Babilonskoj kuli i želji da se dohvate Sunce i Mjesec.

Poznato je iz etnoloških istraživanja i svakodnevnog doživljavanja na selu da i danas ima ostataka praznovjerja: davanje suncu i mjesecu dirigentske palice nad ljudskom sudbinom (Vego 1980: 357-359). I ljudi iz srednjovjekovne Bosne su jednako kao i drugi iz različitih svjetskih kultura rado upotrebljavali likove polumjeseca i različito stilizovane 
simbole sunca i kombinirali ih često na nadgrobnim spomenicima uz jedan ili više križeva, pri čemu likovi polumjeseca i sunca nisu uvijek imali grobno ili heraldičko značenje. Domaći mitovi i legende su ispleteni nebeskim pojavama / silama koje su imale moć nad ljudima, pa čak i nad drugim nadnaravnim stvorenjima: vilama ili zmajevima. "Prema njima, Mjesec se ženi sjajnom zvijezdom, Sunce se umori gledajući lijepe djevojke, a sama lijepa djevojka postaje zvijezda Danica, nakon što je Sunce uzme za ljubovcu" (Efendić 2014: 108).

Bošnjačka mitološka pjesma Djevojka je suncu govorila sačuvala je i drevno vjerovanje vezano za nastanak Zornjače ili zvijezde Danice. Naime, Sunce se u gori, na vodi, zagledalo u lijepu djevojku te je zaigralo od ushićenja. Odmah je bacilo svoje čarobne zrake na nju i privuklo je k sebi. Neznana ljepotica je postala najprije Sunčeva ljubovca, a zatim i zvijezda Danica. (Efendić 2014: 117; Biserje 1972: 7) Narodna predaja i čovjekova opsjednutost nebeskim tijelima načinili su da ime ove zvijezde postane i prezimenom: Danica (< stsl. donbnica > bos. Danica zvijezda Sjevernjača, Danica).

Kako je poslije Sunca i Mjeseca Danica najsjajnije nebesko tijelo vidljivo golim okom na nebu, a i zbog posebnih položaja u kojima je vidljiva, dobila je i nazive Zornjača i Večernjača, a malo je znano da je zvijezda Danica zapravo planeta Venera. Iako posredno, preko ličnoga imena, ova planeta je motivirala i prezime Zuhrić (< ar. Zuhrä - planeta Venera).

Jasno da je položaj u svemiru bio učestao motiv čovjekova razmišljanja, čak na granici opsesije u poimanju granica i spoznavanju Boga. Želja za otkrivanjem dalekoga i nepoznatog tjerala je čovjeka k istraživanju svemira, pa je izučio nebeski sistem, naučio razlikovati i odrediti položaj nebeskih tijela, otkrio elemente nebeske sfere, odnosno postojanje drugih planeta. Otkrivši planete postao je toliko fasciniran i opsjednut njima da se odlučio prema njima identificirati. To je jasno u prezimenima: Behram, Berhamović (< pers. Behrām - planeta Mars) i Vego (< ar. äl-váqi - pad, padanje > Vega - zvijezda u zviježđu Lire).

Sa ustaljivanjem, kršćanstvo i islam su jednako osuđivali ranije astrološke sljedbenike koji su gatali prema zvijezdama, tumačili život prema 
njima utvrđujući zvjezdane karte i na koncu zodijačka sazviježđa. Međutim, figure nebeskih tijela vidljive su i u pomenutim monoteističkim religijama, pa s tim u vezi, na metalnome pečatu Franjevačke provincije Bosne Srebrene iz vremena poslije 1514. godine, vidi se Kristovo raspeće, s posebno stiliziranim prikazom Kristove glave sa sunčevim trakama uz lik polumjeseca i tri reda zvijezda. Dakle, bosanski franjevci su poštovali polumjesec, zvijezde i sunce, dajući im kršćansko, a nipošto astrološko, magično značenje (Fermendžin 1892: 307). Identično je i u islamu čiji je religijski simbol upravo polumjesec i zvijezda. Motiv zvijezde, vjerovatno oslonjen na njezin sjaj, veličinu, kretanje i nedostižnost, sačuvan je i danas u prezimenu Zvizdić (< stsl. $z$ vêzda > bos. zvijezda - nebesko tijelo, lat. stella).

\section{Kult vatre}

Kod primitivnih naroda vatra je imala važno mjesto u životu i kultu. U njoj je čovjek vidio dar bogova i moć natprirodnih bića. O važnosti vatre u kulturnom razvoju čovjeka svjedoče mnoge legende i mitovi o pronalasku vatre, gotovo u svim kulturama svijeta. "Pronalazači vatre kod mnogih naroda imaju slično poreklo, ili su božanska bića ili vladari božanskih atributa. Prometej i Matarisvan su božanska bića koja kradu vatru sa neba da bi je poklonili čoveku. Večni oganj se čuvao u svetilištima, kao u hramu Veste u Rimu." (Grković 1983: 38). Slavenski kult vatre vezan je za vrhovno božanstvo, gromovnika Peruna, boga plamena i ognja, koji bi rasrđen slao gromove i vatru na neposlušne ljude. Zato je čovjek vatru doživljavao emotivno ambivalentno: iako mu je ponudila toplinu, svjetlost, zaštitu od životinja i promjenu u prehrani, od vatre je zazirao zbog njezine siline i nekontrolisanoga dometa usljed kojega je uništavala i ubijala. Vatru su često stvarale mitske nemani u nastrtajima na ljude. Iz svega navedenog, raširilo se vjerovanje da je vatra poslana od boga, a i danas se vjeruje da će svijet skončati u velikom požaru, kao i da poslije smrti postoji mjesto vječne vatre (pakao, džehenem). Zbog takve važnosti u životu i poslije njega, kult vatre je preko različitih leksema našao mjesta i u prezimenima. 


\begin{tabular}{|c|c|c|}
\hline $\begin{array}{l}\text { nazivi } \\
\text { iz kulta } \\
\text { vatre }\end{array}$ & & etimologija i značenje \\
\hline vatra & $\begin{array}{l}\text { Vatrić, } \\
\text { Vatrešević, } \\
\text { Vatrenjak, } \\
\text { Purivatra }\end{array}$ & 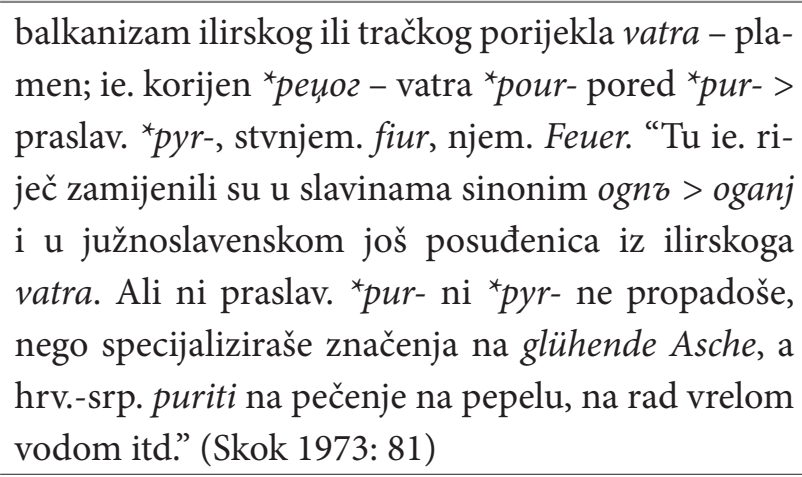 \\
\hline oganj & Ognjenović & stsl. ognz > bos. oganj - vatra \\
\hline plamen & Plamenac & stsl. plamy - plamen, vatra \\
\hline požar & $\begin{array}{l}\text { Požar, } \\
\text { Požarnik, } \\
\text { Požegić }\end{array}$ & $\begin{array}{l}\text { stsl. požeĉi - spaliti > bos. požar - oganj, rasplamsa- } \\
\text { na vatra koja nanosi materijalnu štetu ili ugrožava } \\
\text { ljudske živote }\end{array}$ \\
\hline opalka & Opalka & stsl. opalêti - paliti, spaljivati > bos. opalka - varnica \\
\hline žar & $\begin{array}{l}\text { Žarić, } \\
\text { Žarković }\end{array}$ & $\begin{array}{l}\text { ie. }{ }^{*} g^{u h} e r-- \text { sagorijevati, postajati toplijim > prasl. } \\
\text { *žarz > bos., hrv., srp. žar - žeravica, vrućina, žega; } \\
\text { (usp. Snoj 2016: } 887 \text { ) }\end{array}$ \\
\hline žega & Ožegović & stsl. ožeĉi - opeći > žega - toplina, vrućina \\
\hline žiža $(\mathrm{k})$ & $\begin{array}{l}\text { Žiža, Žižak, } \\
\text { Žižić, Žiško }\end{array}$ & 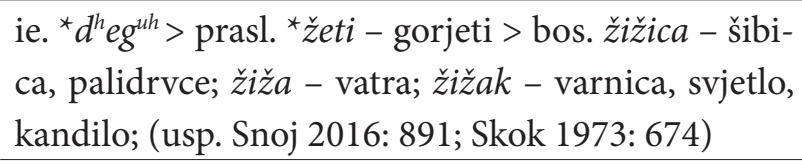 \\
\hline varnica & Varnica & stsl. varz - vrućina \\
\hline viganj & Vignjević & prasl. ${ }^{*}$ vygnz - plamen, oganj (usp. Snoj 2016: 842) \\
\hline prživ & Pržić & $\begin{array}{l}\text { stsl. prižagati - paliti, spaljivati; od pridjeva prživ u } \\
\text { značenju koji peče, ili metaforički prževit u značenju } \\
\text { svadljiv, brz, nagao (usp. Skok 1973: 63) }\end{array}$ \\
\hline
\end{tabular}

\section{Okultizam i šamanizam u prezimeniku}

Među značajnim odrednicama u profiliranju Slavena jasno bi se izdvojila njihova svestrana povezanost s prirodom, preko primarnoga 
bavljenja ratarstvom i stočarstvom, razvijenoga kulta narodne medicine, pa sve do slavenskoga panteona koji inicira važnost slavljenja prirode. Zbog takvoga projiciranja u prirodi, ne čudi da su Slaveni ostvarili višestoljetnu tradiciju razvijanja postupaka, vještina i tehnika kojima se neizravno nastojalo utjecati na tok prirodnih sila, odnosno energiju svijeta i svemira, s intencijom njihove mijene u skladu s vlastitom voljom, a s ciljem potčinjavanja i zaštite. Takvo djelovanje prožimalo se sa duhovnim, ali se razvilo kao zasebna disciplina - magija. Magija je razvila dvije poddiscipline: bijelu i crnu magiju (koje su se razlikovale po tome da li su stupale u interakciju s božanskim ili demonskim silama), a u korespondenciji s animizmom, demonizmom, šamanizmom i sl. razvila je vlastite tehnike djelovanja: bajanje, čaranje ili vračanje, prizivanje, uricanje, bacanje kletve i sl. Magiju su provodili posebno izučeni, a prirodom i višim silama nadareni pojedinci, koji su različito nazivani: vračar / vračara, gatara, faletar, karapandža, bajalica, vještica, prorok. Kolika je bila raširena magijska praksa i koliku su popularnost uživali njezini realizatori svjedoči unaprijed navedeni sinonimski nomina agentis niz, ali naročito niz prezimena koji su ti oblici motivirali:

\begin{tabular}{|c|c|c|}
\hline $\begin{array}{l}\text { nomina } \\
\text { agentis }\end{array}$ & prezimena & etimologija i značenje \\
\hline bajaš & Bajalica, Bajaš & 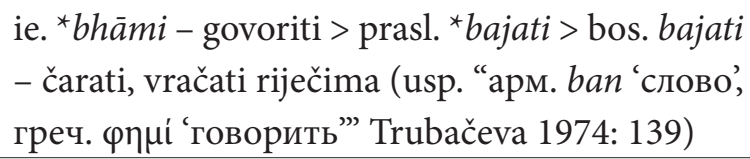 \\
\hline faletar & Faletar & $\begin{array}{l}\text { tur. fal - gatanje, bajanje; prema tur. fal açmak - } \\
\text { gatati, predskazivati (Đinđić i dr. 1997: 357) }\end{array}$ \\
\hline \multirow[t]{2}{*}{$\operatorname{gatar}(\mathrm{a})$} & $\begin{array}{l}\text { Gatalo, Gatara, } \\
\text { Gatarić }\end{array}$ & stsl. gatati > bos. gatati - proricati, bajati, vračati \\
\hline & Karapandža & $\begin{array}{l}\text { tur. kara - crn + pers. penğe - kandža, nokti } \\
\text { (Đinđić i dr. 1997: 785; Škaljić 1989: 396, 509) > } \\
\text { bos. karapandža - sa crnim pandžama, vještica; } \\
\text { prema pučkom vjerovanju to je osoba, a najče- } \\
\text { šće žena, nadnaravnih moći kojima se služi is- } \\
\text { ključivo kako bi naudila ljudima, životinjama i } \\
\text { biljkama }\end{array}$ \\
\hline
\end{tabular}




\begin{tabular}{|c|c|c|}
\hline $\begin{array}{l}\text { nomina } \\
\text { agentis }\end{array}$ & prezimena & etimologija i značenje \\
\hline vrač & $\begin{array}{l}\text { Vrač, Vračar, } \\
\text { Vračarić, } \\
\text { Vračević, } \\
\text { Vračić }\end{array}$ & $\begin{array}{l}\text { stsl. } v r a c ̌ z>\text { bos. vrač - osoba upućena u okultna } \\
\text { znanja i magiju; imenica vrač nije uvijek imala } \\
\text { negativan predznak, najprije je u staroj slaven- } \\
\text { skoj kulturi označavala liječnika, odnosno oso- } \\
\text { bu koja je uglavnom liječila travama }\end{array}$ \\
\hline vještica & $\begin{array}{l}\text { Vještica, } \\
\text { Vištica }\end{array}$ & $\begin{array}{l}\text { stsl. vêsti - znati, poznavati, biti svjestan čega ili } \\
\text { biti vješt u čemu > bos. vještica / vještac - ona / } \\
\text { onaj koji zna, koji je vješt u nečemu; danas oblik } \\
\text { vještica označava ženu koja je vješta da drugima } \\
\text { nanese zlo; međutim, da je u ovome obliku doš- } \\
\text { lo do semantičkoga pomjeranja svjedoči činje- } \\
\text { nica da kod starih Slavena vještice nisu oduvijek } \\
\text { imale negativan predznak, odnosno da se vještac } \\
\text { zvao onaj koji je mnogo znao, koji je bio vješt, a } \\
\text { ostaci takvoga interpretiranja opstoje kod Čeha i } \\
\text { dan danas pa vieštac znači proroka, to jest onoga } \\
\text { koji i buduće stvari zna. (usp. Čiča 2002: 53) }\end{array}$ \\
\hline prorok & Prorok & $\begin{array}{l}\text { stsl. prorokb - koji proriče prema stsl. proricati - } \\
\text { proricati, pretkazivati }\end{array}$ \\
\hline
\end{tabular}

U svijesti čovjeka još uvijek preovladava mišljenje da je sve što se desi tokom života unaprijed predodređeno. To je povezano sa značenjem leksema sudbina / kob, što je također poslužilo kao motiv u prezimenu: Kobić (stsl. kobr > bos. kob - sudbina, uglavnom loš usud - mitološki termin iz gatanja). Još dublje vjerovanje se odnosilo na sve zlo koje se dogodi, doživi tokom života, da je kazna od boga kao tvorca sudbine, koji kažnjava ljude za počinjene grijehe preko svojih sluga, demona i vještica. Tako se i danas zadržalo fatalističko shvatanje, pa kad neko umre, kaže se: “Tako mu je bilo suđeno!”, a kad neko ozdravi: “Tako mu je Bog odredio!”, “Bog ga pogledao!” ili “Bog ga spasio!”. Otuda i vjerovanje da je bolest živa, te da se može bajanjem istjerati iz tijela. Za većinu primitivnih naroda bolesti su natprirodnoga porijekla i liječenje se za tim povodi, pa su ljudi često spas tražili upravo kod ljudi koji 
komuniciraju s natprirodnim silama, bilo da predskazuju budućnost ili liječe, tj. koji se bave magijom. Učestao je bio i suprotan smjer obolijevanja, jer bolest dolazi i kada se nabace čini iz mržnje i zavisti, a one se nabacuju preko vračara. Bolesti se dobivaju i preko uroka, a u tom slučaju najčešće obolijevaju djeca. To je iznjedrilo mnoštvo slavenskih apotropejskih tzv. ružnih imena s opasnom semantikom koja je trebala da odagna zle sile od djeteta. U ovakvim slučajevima, ljudi su se često obraćali vračarama, a kasnije s dolaskom kršćanstva i islama praksa se nastavila odlascima popovima i hodžama, koji bi izrađivali razne (h)amajlije u službi zaštite djece.

\section{Žena kao simbol natprirodnih sila, žrtva iskupljenja i moćna krvnica}

Zajedno sa šamanističkim metodama liječenja kao nematerijalnim kategorijama liječenja zapisima, (h)amajlijama i sl., sprovodilo se i racionalno liječenje koje se temeljilo na praktičnim iskustvima iz prirode od ranijih generacija - iscjeljivanje biljkama, mineralima, izlučevinama i sl. Ljudi koji su lijekove pronalazili u raznim travama kao smjeli empirici razvijali su granu narodne medicine i postajali pučki ljekari, ali su u društvu ipak smatrani onima koji komuniciraju s natprirodnim, i opet prozivani vračarima. Narodni ljekari su uglavnom bivale osobe u poznijim godinama, oba spola, a liječili su pravilom: muškarci obično za spoljašnje bolesti (rane, prijelomi i sl.), a žene više za unutrašnje bolesti.

Žene su skupljale ljekovito bilje, sušile ga i pretvarale u čaj ili izrađivale razne meleme i time su liječile. Radnje koje su bile vezane za krvarenje isključivo su bivale posao muških ljekara (usp. Đuričić - Elazar 1958: 140; Božović 1987: 258). U osnovi ove podjele leži stari slavenski društveni poredak i njihovo narodno vjerovanje. Poznato je da su se kod Slavena magijski obredi vezali za ženu kao simbol natprirodnih sila. Bilo da su žrtve iskupljenja ili moćni krvnici, žene su bile opterećene narodnim vjerovanjem da djeluju i utječu na okultne sile. Posredničke sposobnosti bile su oličene u obrednome liku vještice. Često su žene i same bile prožete tom vjerom, pa su nadarenost najčešće usmjeravale 
na ljubavne odnose, kako bi zadobile voljenog muškarca ili pobijedile suparnicu (usp. Kont 1989: 215-219). U većini slučajeva, žena je bila, u stvari, žrtva društvene podređenosti koja se tokom stoljeća pojačavala, da bi u historiji kulminirala inkvizicijom: od XIII st. svjetovni i crkveni pravnici prihvatili su pučka vjerovanja o vješticama te je njihovo proganjanje u zapadnoj i srednjoj Europi trajalo sve do druge polovice XVIII st. U prethodnoj tvrdnji leži i razlog što je u ovoj skupini prezimena povećan broj onih u kategoriji ženskoga roda: usp. Bajalica, Vještica, Vištica, Karapandža, Gatara.

\section{Tvorba prezimena}

S obzirom na tvorbeni proces, prezimena kojima su elementi iz domene mitologije i magije poslužili kao motivi nastanka moguće je dijeliti trojako: 1 . netvorena, prosta, nedjeljiva ili asufiksalna prezimena, 2. sufiksalna ili prezimena tvorenice i 3. prezimenske složenice.

Kod prostih prezimena motivirajući je leksem jednak prezimenu, a može biti naziv za čudesno / čudovišno stvorenje antropomorfno / zoomorfno biće, šamane, teonime ili imena nebeskih tijela: npr. Vila, Drakul, Džin, Faletar, Vrač, Perun, Danica. Takva prezimena nastajala su bez tvorbenoga čina, tj. onimizacijom. Nekada su na korijenski morfem, odnosno motivirajući leksem, dodavani nastavci pa su dobijani raznorodni derivacioni oblici koji su jednako nastajali izravnim imenovanjem u odnosu na realije iz mitološke ili magijske domene, imenujući direktno nositelja, te su iz tog razloga ovako tvorena prezimena uvjetno rečeno "neizvedena”. Takva prezimena su uglavnom u značenju nomina agentis i svjedoče realizatore raširene magijske prakse i njezinu popularnosti, npr. Gatara, Gatalo, Bajalica, Vještica, Vištica. Iako su danas prezimena lišena značenja, nosioci ovakvih prezimena znaju ih osjećati stigmatizirajućim, budući da je savremeno bosanskohercegovačko društvo dominantno monoteističko, isključujuće u pogledu magijskoga djelovanja.

Kod sufiksalnih, prezimena se sastoje od osnove (motivirajućega leksema) i sufiksa, npr. -ica: Vilenica; -ac: Zmajevac, i najčešće hipokoristično-patronimskim sufiksom -ić: Vilić, Aždajić, Drakulić, Divić, Džinić, Peruničić, Gatarić, uz one s infiksalnim dijelom -ov-/-ev-, odnosno 
pravim patronimskim sufiksima-ovićl-ević:Zmajević, Bijesović, Divović, Džinović, Đinović, Perunović, Vatrešević, Vignjević. Pri sufiksalnome načinu tvorbe prezimena, tvorbeno značenje se moglo ostvariti kao umanjenica - Vilenica, ili uvećanica - Perušina.

Slaganjem kao tvorbenim načinom kojim od dviju riječi nastaje jedna - složenica, nastala su složena prezimena koja u svojoj strukturi na drugome mjestu uvijek imaju imenicu kao samostalnu riječ, što ih čini imeničkim složenicama, dok se u prvome dijelu pojavljuje također imenica: Alavuk, Vilogorac, ili pridjev: Karapandža te glagol: Purivatra.

\section{Osvrt na etimologiju}

Drevna paganska tradicija i baština vezana za ruralna vjerovanja, običaje i magiju, uvjetovali su to da su Slaveni imali izrazito razvijene magijske obrede, rituale i u njima pokrete koji su se održali do danas (npr. kucanje rukom u drvo i kamen protiv uroka, tj. da ne čuje zlo), koji su zbog svoga značaja proželi svaki segment života i tako ušli u umjetničke, odnosno mitološke - književne i nadasve identifikacijske - onomastičke pore. S tim u vezi, ne čudi da je najveći broj ovog onomastičkoga blaga - prezimena koja su motivirana mitološkim i magijskim motivima, slavenskoga porijekla jer se kao takvo i razvilo u svojoj kolijevci: Alavuk, Bijesović, Danica, Divac, Divčić, Divić, Divović, Divoš, Divović, Divanović, Divjak, Divjakinja, Divković, Divljan, Divljanović, Drakul, Drakulić, Gatalo, Gatara, Gatarić, Ognjenović, Opalka, Ožegović, Plamenac, Požar, Požarnik, Požegić, Prorok, Pržić, Varnica, Vignjević, Vila, Vilenica, Vilandečić, Vilogorac, Vilić, Vještica, Vištica, Vrač, Vračar, Vračarić, Vračević, Vračić, Zmajevac, Zmajević, Zvizdić, Žarić, Žarković, Žiža, Žižak, Žižić, Žiško.

Suživot stanovnika Bosne i Osmanlija u zajedničkome carstvu od kraja XV do druge polovine XIX stoljeća imao je među ostalim za posljedicu posudbu velikoga broja ne samo turskih nego i perzijskih i arapskih riječi koje je turski ranije posudio. Na taj način, jezičkim posredovanjem turskoga, u bosanski jezik je ušlo više hiljada izvorno arapskih i perzijskih riječi. To je razlogom zašto su orijentalizmi drugi po učestalosti, 
odosno prvi iz posuđeničkoga korpusa koji su po frekventnosti motivirali prezimena inspirirana mitološkim, odnosno magijskim elementima. Uzrok jezičkoga posuđivanja iz drugih jezika ostvaruje se u skladu s civilizacijskim i kulturnim prilikama u kojima se nalazi društvo i samim tim potrebama jezika da imanentno preuzima određeni fond leksičkih jedinica. Iako je u islamu strogo zabranjeno magijsko djelovanje, činjenica je da su mnogi orijentalizmi motivirali prezimena iz našeg korpusa, npr. Alavuk, Aždajić, Bajalica, Bajaš, Behram, Berhamović, Džin, Džinalija, Džinić, Džino, Džinović, Đinović, Đino, Faletar, Karapandža, što će reći da se tradicija koja je postajala prije dolaska Osmanlija morala nastaviti, istina zavijena u novome ruhu s obzirom na izmijenjene kulturne i religijske prilike u Bosni i Hercegovini.

Obuhvaćeni prezimenski korpus potvrdio je i jezičke dodire s ilirskim jezikom kroz prezimena koja je motivirao balkanizam ilirskog porijekla vatra: Vatrić, Vatrešević, Vatrenjak, Purivatra.

Neke jezičke posudbe sežu do vremena kada su Slaveni još zajedno živjeli u svojoj pradomovini, npr. iz germanskoga jezika, da bi se isti jezički dodiri nastavili tokom srednjega vijeka, a naročito intenzivirali $\mathrm{u}$ vrijeme austrougarske uprave u Bosni i Hercegovini, kada se i broj njemačkih posuđenica umnožio. Tim više je zanimljivo što u ekscerpiranim primjerima ne nalazimo germanizme.

\section{Zaključak}

Priče o nadnaravnim radnjama bogova ili junaka, o njihovim sukobima sa zlodusima i nemanima, utemeljile su starobosansku mitologiju i mitomaniju, osvijetlile domaću srednjovjekovnu magiju i uopće kulturu. U lancu usmene predaje, prepričavanje mitova je bilo ritualni događaj s trivijalnom svrhom, ali i u službi obnavljanja kolektivnoga pamćenja, osjećaja pripadnosti matičnoj cjelini, odnosno u identitarnoj službi. Na mitskim su se pripovijedanjima opetovali događaji nastanka svijeta, čovjeka, zajednice i interakcije među svakojakim, prirodnim i natprirodnim, bićima. Zato je danas brojnim primjerima, pa i kroz onomastiku, moguće pokazati da je bosanskohercegovačka mitologija 
sačuvala elemente iz starijega slavenskoga i starobosanskoga perioda budući da obiluje kazivanjima i vjerovanjima u čuda, kletve, magiju, uroke, zle sile, duhove. Kako u kulturi teže dolazi do diskontinuiteta, ova duboko ukorijenjena tradicija je u bosanskohercegovačkome društvu imala produženi rukav čak do perioda zakonskoga poprezimenjavanja (XIX stoljeće), kada je našla odraz i u motivima koji su poslužili $\mathrm{u}$ procesu identifikacije, time potvrdivši svoj značaj u svjetonazoru. Tako su brojna prezimena motivirana čudesnim ili čudovišnim stvorenjima, antropomorfnim ili zoomorfnim bićima te likovima paganskih božanstava. U toj skupini motiva prednjačili su: 1. vile i razne nemani: divovi, vukodlaci, zmije, zmajevi; 2. slavenski paganski panteon - teonimi; 3. nebeska tijela i 4. elementi kulta vatre. Identificirajući se kao žrtve iskupljenja i moćni krvnici, ljudi su oblikovali zasebnu skupinu prezimena koja su motivirana magijskim elementima, a koja svjedoče svestranu povezanost čovjeka s prirodom i kroz razvijeni kult narodne medicine i ovladavanje prirodom. Tako su nastala prezimena u značenju nomina agentis, npr. Falatar, Gatara, Gatalo, Bajalica, Vještica, Vištica, Vrač. Iako su danas prezimena lišena značenja iz najprostijeg razloga što je funkcionalno svojstvo prezimena "svedeno na 'golu' denotativnost prezimenskoga lika - obavlja svoju identifikacijsku i diferencijacijsku funkciju” (Frančić 2013: 107), nosioci ovakvih prezimena znaju ih osjećati stigmatizirajućim, budući da je savremeno bh. društvo dominantno monoteističko, isključujuće u pogledu magijskoga djelovanja. Katkad kao prezrive, podrugljive ili ironične biljege, svoja prezimena doživljavaju i nosioci prezimena: Aždajić, Alavuk, Bijesović, Divjakinja, Drakul, Karapandža i sl., iako pejorativnoj interpretaciji tu nema mjesta.

S obzirom na tvorbeni proces, prezimena kojima su elementi iz domene mitologije i magije poslužili kao motivi nastanka, nastajala su trojako: kao prosta ili asufiksalna, zatim sufiksalna prezimena i kao prezimenske složenice. Ovaj prezimenski korpus, iako je dominantno motiviran domaćim riječima, svjedoči i brojne orijentalizme i kao takav prezentira ovo podneblje kao jezičku sliku ne samo onomastičkog identifikacionog ostvarivanja nego i jezičkoga bogaćenja, međujezičkih dodira i 
procesa akulturacije. Budući da umiru posljednja koljena, kazivači koji prenose naslijeđene mitove, čiji je učinak borbenost, radinost, veličanje tradicionalnog i identitarnog, dobro je da su lajtmotivi koji se nalaze $\mathrm{u}$ temelju bosanskohercegovačke kulture, pored nekolicine knjiga, balzamirani i u prezimenima u kojima se može očekivati spas od iščeznuća.

\section{Izvori}

Janjatović, Đorđe (1993): Prezimena Srba u Bosni, Prosvetatrgovina d.d., Sombor.

Mehić, Jasmin (2017): Genealoška istraživanja zavidovićkih prezimena, Centar za kulturu, Zavidovići.

Mrđen, Slobodanka (1987): “Onomastika sela Hasanbegovci (Brajići) kod Glamoča”, Onomatološki prilozi VIII, SANU, Beograd, 449-466.

Milićević, Risto (2005): Hercegovačka prezimena, Svet knjige, Beograd.

Nosić, Milan (2000): Bosansko-hercegovačka hrvatska prezimena II, Hrvatsko filološko društvo, Rijeka.

Nosić, Milan; Vidinić, Magdalena (1999): Bosansko-hercegovačka hrvatska prezimena I, Hrvatsko filološko društvo, Rijeka.

Nosić, Milan (1998): Prezimena zapadne Hercegovine, Hrvatsko filološko društvo, Rijeka.

Pandžić, Jerko (1999): Hercegovačka imena i nazivlje, Onomastička ispitivanja, Naklada Kosinj, Zagreb.

\section{Literatura}

Anić, Vladimir (1996): Rječnik hrvatskoga jezika, Novi Liber, Zagreb.

Biserje (1972): Biserje - Izbor iz muslimanske književnosti, priredio Alija Isaković, Stvarnost, Zagreb.

Božović, Dragan (1987): "O narodnoj medicini stanovništva Tuzle s okolinom”, u Zbornik radova XXXIV Kongresa saveza Udruženja folklorista Jugoslavije, Tuzla, 257-262.

Burkhart, Dagmar (1989): Kulturraum Balkan. Studien zur Volkskunde und Literatur Südosteuropas, Reimer, Berlin - Hamburg. 
Čajkanović, Veselin (1941): O srpskom vrhovnom bogu, Srpska kraljevska akademija, Zadužbina Milana Kujundžića, Beograd.

Čiča, Zoran (2002): Vilenica i vilenjak: sudbina jednog pretkršćanskog kulta u doba progona vještica, Institut za etnologiju i folkloristiku, Zagreb.

Deretić, Jovan (2007): Istorija srpske književnosti, Sezam book, Beograd.

Đinđić, Slavoljub; Teodosijević, Mirjana; Tanasković, Darko (1997): Türkçesirpça sozluk, Ankara.

Đorđević, Tihomir R. (1953): "Vampir i druga bića u našem narodnom verovanju i predanju”, SEZ 66, 147-282.

Đuričić, Aca; Elazar, Samuel (1958): Pregled istorije farmacije Bosne $i$ Hercegovine, Centralni higijenski zavod, Sarajevo.

Efendić, Nirha (2014): “Tematika i motivika mitoloških pjesama u bošnjačkoj usmenoj tradiciji”, Sarajevski filološki susreti II, Zbornik radova II, Sarajevo, 105-119.

Fermendžin, Eusebius (1892): Acta Bosnae potissimum ecclesiastica cum insertis editorum documentorum regestis ab anno 925 usque ad annum 1752 / collegit et digessit.

Filipović, M. S. (1948): “Tragovi Perunova kulta kod južnih Slavena”, Glasnik Zemaljskog muzeja III, Sarajevo, 63-80.

Frančić, Anđela (2013): "O prezimenu Ugrin i njegovim inačicama”, XI. Međunarodni kroatistički znanstveni skup, Pečuh, 97-112.

Franković, Mijo (1987): "Kult drveta u životu i običajima stanovništva sjeveroistočne Bosne", u: Zbornik radova XXXIV kongresa Saveza udruženja folklorista Jugoslavije, Tuzla, 251-255.

Grković, Milica (1983): Imena u dečanskim hrisovuljama, Filozofski fakultet u Novom Sadu, Institut za južnoslovenske jezike, Novi Sad.

Katičić, Radoslav (2007): “Čiji to dvor stoji na gori?”, Filologija 48, 75-113.

Kont, Fransis (1989): Nastanak i razvoj slovenskih civilizacija u Evropi (VIXIII vijek), Tom I i Tom II, Biblioteka Retrospektive, Beograd.

Nedić, Vladan (1977): Jugoslovenska narodna lirika. Antologija narodnih lirskih pesama, Srpska književna zadruga, Beograd. 
Plas, Pieter (2010): “Vukovi i smrt: tanatološko značenje vuka u tradicijskoj kulturi zapadnojužnoslavenskog područja”, Narodna umjetnost 47/2, 77-95.

Popović, Jovo (1935): Kroz planine Bosne i Hercegovine, Planinarska društva u Sarajevu, Sarajevo.

Radin, Ana (1996): Motiv vampira u mitu i književnosti, Prosveta, Beograd.

Schneeweis, Edmund (1935): Grundriss des Volksglaubens und Volksbrauchs der Serbokroaten, Celje.

Skok, Petar (1971-1974): Etimologijski rječnik hrvatskoga ili srpskoga jezika, I-IV, JAZU, Zagreb.

Slavjanskie drevnosti I (1995): Slavjanskie drevnosti: etnolingvističeskij slovar', T. 1, A-G, Meždunarodnye otnošenieja, Moskva, 1995.

Snoj, Marko (2016): Slovenski etimološki slovar Tretja izdaja, Inštitut za slovenski jezik, Ljubljana.

Svešnikova, Tatjana N. (1990): "Volk v kontekste rumynskogo pogrebalonogo obrjada", Issledovanija v oblasti balto-slavjanskoj duchovnoj kultury, Moskva, 128-134.

Šimundić, Mate (2006): Rječnik osobnih imena, Matica hrvatska, Zagreb.

Škaljić, Abdulah (1989): Turcizmi u srpskohrvatskom jeziku, Svjetlost, Sarajevo.

Trubačeva, O. N. (1974): Etimologičeskij slovar slavjanskih jazykov, Vypusk 1, Akademija nauk SSSR, Institut russkogo jazyka, Moskva.

Vego, Marko (1980): Iz istorije srednjovjekovne Bosne i Hercegovine, Svjetlost, Sarajevo.

Žepić, Milan (1985): Latinsko-hrvatski ili srpski rječnik, Školska knjiga, Zagreb. 


\title{
The dragon of Bosnia or is away with the fairies - mythological and magical motifs in the surnames of Bosnia and Herzegovina
}

\begin{abstract}
Mythology and fantasy, the elements of the time very long ago, have been interwoven with the contemporary language in oral literatur forms and onomastics. These elements of the past, although supposedly left very far behind, keep appearing in some new forms in surnames. This approach attempts to identify the characteristics of surnames in semantic, etymology and some other branches of linguistics. Mythological motifs are no longer used for surname formation since that category disappeared long time ago. Still, these surnames are worth the scientific exploration and corpus positioning. So, originally cited and described and analyzed examples in this paper represent a substantial philological, ethnological and anthropological treasure.
\end{abstract}

Key words: anthroponymy, onomastic, surnames, mythology, giants, fairies, dragons, pagan Slavic gods

Izjava autora o nepostojanju sukoba interesa i poštivanju općih etičkih kodeksa:

Autor potvrđuje da ne postoji nikakav stvarni ili mogući sukob interesa vezan za ovaj tekst te da je tekst napisan u skladu s etičkim kodeksima prema preporukama COPE (Committee of Publishing Ethics). 